\title{
METHYLATION OF PROLACTIN AND OXYTOCIN HORMONE GENES; PHYSIOLOGICAL FUNCTIONS AND ROLES IN DISEASE STATES
}

\section{Manoj G Tyagi, Deepak G Shewade*, Megha Chaudhary, Mohammed I Wani and Shyam S Yadav}

College of Paramedical Technology NIMS University

Jaipur, Rajasthan and Department of Pharmacology*, JIPMER Pondicherry

Article Info: Received 15 February 2018; Accepted 25 March. 2019

Cite this article as: Tyagi, M. G., Shewade, D. G., Chaudhary, M., Wani, M. I., \& Yadav, S. S. (2019). METHYLATION OF PROLACTIN AND OXYTOCIN HORMONE GENES; PHYSIOLOGICAL FUNCTIONS AND ROLES IN DISEASE STATES. Journal of Biomedical and Pharmaceutical Research, 8(2).

DOI: https://doi.org/10.32553/jbpr.v8i2.584

Address for Correspondence: Dr Manoj G Tyagi, College of Paramedical Technology, NIMS University, Jaipur, Rajasthan 313021

Conflict of interest statement: No conflict of interest

\section{ABSTRACT:}

DNA methylation is the key mechanism in epigenetic events involved in gene silencing and gene genome stability. The two important hormones involved in social behaviour, lactation and parturition are Oxytocin and Prolactin. There is growing interest in epigenetic modification of oxytocin and prolactin in neurotransmission interaction and their functional significance. This review outlines the influence of DNA methylation of genes of oxytocin and prolactin hormones/receptors and impact on their biological roles and influence on endocrine function in mammals.

Keywords: Prolactin, Oxytocin, receptor, DNA methylation, epigenetics

\section{INTRODUCTION}

The two neuropeptide hormones oxytocin and prolactin play an important role in social behaviour, parturition and lactation (1-3). Both the hormones are also involved in the response to stress via an interaction with serotonin system. In mammals, DNA methylation is believed to mediate the modulation of transcription and functional responses. In mammals, the cytosine bases at position 5 in $\mathrm{CpG}$ dinucleotides are modified genome-wide by dedicated methyltransferases to produce 5-methylcytosine $(5 \mathrm{mC})$, which can be further oxidized by the Ten eleven translocation (TET1, 2, and 3) enzymes (4-6) to 5-hydroxymethylcytosine (5hmC), 5-formylcytosine (5fC), and 5carboxylcytosine (5caC)

(Fig.1). Neurobiologically, OXT is synthesized by the OXT gene in magnocellular neurons in the paraventricular and supraoptic nuclei of the hypothalamus. OXT is then transported along axonal projections to the posterior lobe of the pituitary, where it is stored in secretory vesicles before being released into the peripheral blood. In addition, dendritic release of OXT occurs into the extracellular space with diffusion through the brain. Emotional processing and stress have been found to affect the degree of methylation in specific brain regions like the fusiform, amygdala and 
insula. Oxytocin receptors are synthesised by the Oxytocin Receptor (OXTR) gene, which expresses both centrally in the brain and within peripheral organs (7-8). In this way, OXT has both peripheral and central functions. OXTR is located on human chromosome 3p25.3. The OXTR gene spans 17 kilobytes $(\mathrm{kb})$ and contains 3 introns and 4 exons. Exons 1 and 2 correspond to non-coding regions while exons 3 and 4 encode the amino acids of the oxytocin receptor.For the Prolactin on the other hand, cis acting elements are characterised in the proximal region of the promoter sequence. DNA methylation down regulates prolactin gene transcription while hypomethylation may cause enhanced gene expression (9). This article examines the interaction of oxytocin and prolactin and their epigenetic modification in physiological and disease states.

\section{Methylation of oxytocin gene DNA and role in diosrders:}

Using the techniques of genomic sequencing, several groups have indeed presented evidence linking site-specific methylation in promoter regions and transcriptional inactivity (10). However, the great majority of the data collected concerns GC-rich and TATA-less promoters and 59 upstream regions of $X$-linked housekeeping genes that are associated with CpG islands (11). The implication of promoter methylation in gene regulation is further supported by results from functional analyses performed by transfection assays.OXTR DNA methylation and outcomes in various domains are emerging in the literature. These include positive associations between OXTR DNAmethylation and callous-unemotional traits in youth, social cognitive deficits in ASD, rigid thinking in anorexia nervosa, affect regulation problems and mood deficits as well as limbic regions linked with facial and emotional recognition. In mouse models, OXTR DNA methylation patterns have been correlated with differential OXTR expression in different body tissues. In different brain areas, differing DNA methylation at specific CpG regions within the OXTR occurred with differential expression of OXTR (12). The differential OXTR expression is considered to relate to a diversity of animal social behaviours arising from the limbic brain structures. Though animal and human OXTR gene promoter brain regions differ, the inference is that DNA methylation differences result in OXTR transcription changes with impact on human social and emotional behaviour, affect regulation problems (13-14) and mood deficits (15) as well as limbic regions linked with facial and emotional recognition (16). In contrast, reduced OXTR DNA methylation has been associated within indicators of perinatal stress (17), postnatal depression (18), social anxiety (19) and autism in children.

\section{Prolactin gene methylation and effects:}

The PRL superfamily genes, present in large clusters on chromosome 13 in the rodents and on chromosome 6 in humans, can be classified into four clusters according to their position and orientation. During lactation, prolactin activates STAT5 (Signal Transducer and Activator of Transcription), which binds to conserved DNA sequence motifs inpromoters of milk protein genes to stimulate their expression (20) (Fig.2). At drying-off, mammary involution is characterised by a rapid decrease in milk protein gene expression including $\alpha \mathrm{S} 1$ casein (21). The $\alpha \mathrm{S} 1$-casein promoter features a doublet STAT5 binding site containing $3 \mathrm{CpG}$ dinucleotides. During lactation, these $\mathrm{CpG}$ dinucleotides are hypomethylated but become methylated following Escherichia coli infection of the gland.The role of site-specific decreased level of DNA methylation on the induction of gene expression has previously been studied most extensively in cultured cell lines and in systems with drug induced inhibition of DNA methylation. Earlier in vivo analysis indicated that tissue-specific expression can be correlated to the site-specific hypomethylation of $-\mathrm{C}$ - residues in several genes and implicated a role for hypomethylation in the 2| P a g e 
developmental regulation of genes of higher organisms. The correlation established in this investigation between site-specific DNA hypomethylation/ hypermethylation and altered expression of PRL and $\mathrm{GH}$ genes under alternate physiological states establishes the role of DNA methylation on gene regulation from different perspectives. The correlation of extent of DNA hypomethylation with tissuespecific expression of genes has been limited to the steady state level of expression, whereas results of this investigation demonstrate a dynamic state of site-specific DNA hypomethylation and hypermethylation of genes occurring concurrently with the naturally coordinated transition from one state of expression to another.

Results presented in this study also reveal certain basic differences in the methylation pattern of PRL gene sequences between rat pituitary gland and ratpituitary tumor cells in culture. Though the methylation state of the 5 '-end - GCGC- sequences can be correlated with the state of expression of PRL gene in cultured cells the same is not true for the hormonal modulation of expression of PRL gene in the pituitary gland of the intact animal under physiological situations such as pregnancy and lactation. Results of this report are from whole pituitary gland in which the PRL producing lactotrophs. In mammalian genomes, CpGs are present at one-fifth of their expected frequency due to the spontaneous conversion of 5-methylcytosine into thymine by deamination (22-23). The PRL superfamily genes have a relatively low frequency of CpGs, and the number of $\mathrm{CpGs}$ varies among the superfamily genes around the transcription start sites. It was hypothesized that DNA methylation may be a possible mechanism to cause mutation, producing variations in the number of CpGs. Indeed, the number of $\mathrm{CpGs}$ is low in rat PL-I, which has a T-DMR (24). It is not known, however, if there are TDMRs in the superfamily members.

\section{Estimation of DNA methylation:}

The technique of estimation of DNA methylation has been described by Gouin et al (25) using pyrosequencing. To investigate oxytocin receptor DNA methylation, a total of three sets of outside primers and four sets of inside primers can be developed to probe all CpG sites within the target regions (promoter, intron 1, enhancers). The nested reverse primers are biotinylated for pyrosequencing (IDT Technologies). 500 ng of DNA is treated with sodium bisulphite (EZ Methylation Gold, Zymo Research) and undergo two rounds of PCR amplification (1. $95 \mathrm{C} \times 15 \mathrm{~min}$, [94 $\times 1 \mathrm{~min}$, Primer TM * $1 \mathrm{~min}, 72 \mathrm{C} * 1 \mathrm{~min}$ ] for 35 cycles, $72 \mathrm{C} * 10 \mathrm{~min}$; $2.95 \mathrm{C} \times 15 \mathrm{~min}$, [94 $\times 1 \mathrm{~min}$, Primer TM $* 1 \mathrm{~min}, 72 \mathrm{C} * 1 \mathrm{~min}$ ] for 40 cycles, $72 \mathrm{C} * 10 \mathrm{~min})$. The subsequent PCR product then undergoes gel electrophoresis to confirm the purity and the success of the amplification protocol. $20 \mathrm{ul}$ of the PCR product is then used to perform pyrosequencing using PyroMarkQ24 (Qiagen) according to the manufacturer protocol. The methylation percentage at each individual CpG site was analyzed and exported using PyroMark Q24 software (Qiagen).

Prolactin and oxytocin gene methylation and implications in disease: In women with polycystic ovarian disease CpG sites were associated with hypermethylation of prolactin gene (26). The temporal regulations of PRL and $\mathrm{GH}$ gene expression in gestation and lactation are physiological events induced by physiological modulators and occur in specialized terminally differentiated cell types. The regulatory signals are programmed in the cell system itself and are not created by external agents or by experimental manipulation of the in vivo system. The prolactin related protein-1-gene was exclusively hypermethylated in trophoblast cells and therefore a role in plaentogenesis and progression of pregnancy (27-28). Many studies on the other hand have clearly depicted the role of gene methylation of 
oxytocin in Asperger syndrome and autism (29). Oxytocin is now shown in the regulation of social behaviour and considered a hormone of affection. In a study conducted by Durrin et al it was shown that two DNase 1 hypersensitive sites of $5^{\prime}$ to the prolactin gene in pituitary tumors of rats and that coding regions were hypomethylated at MSP1 restriction enzymes sites (30).

General aspects of DNA methylation and impact on diseases: Methylation either hypo or hyper have been implicated in various cancers like the chronic lymphocytic leukemia, ovarian cancer and colon cancer and also in orthopaedic disorders (31). Therefore there is growing research on inhibitors of methyltransferase enzymes and FDA in the USA has approved two drugs 5-aza-cytidine and 5-aza-Cdr for treatment of leukemia and related disorders (32). An intensive review of the role of DNA methylation in behavioural and affective disorders has been illustrated in a text book published by the Elsevier group initially in 2014 and focussed on epigenetic factors that affect biological psychiatry (33).

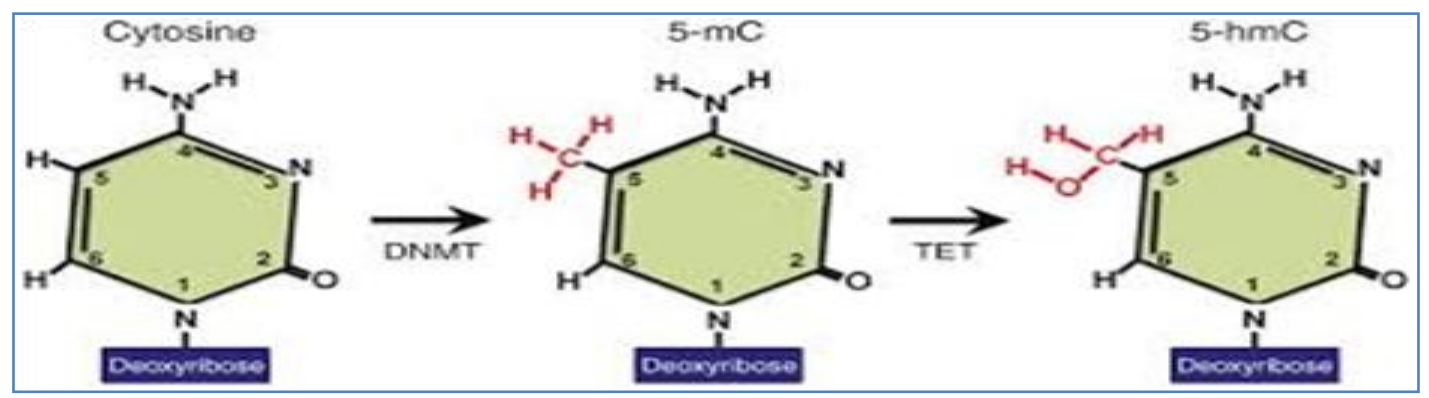

Figure 1: Methylation of cytosine residues and enzymes involved

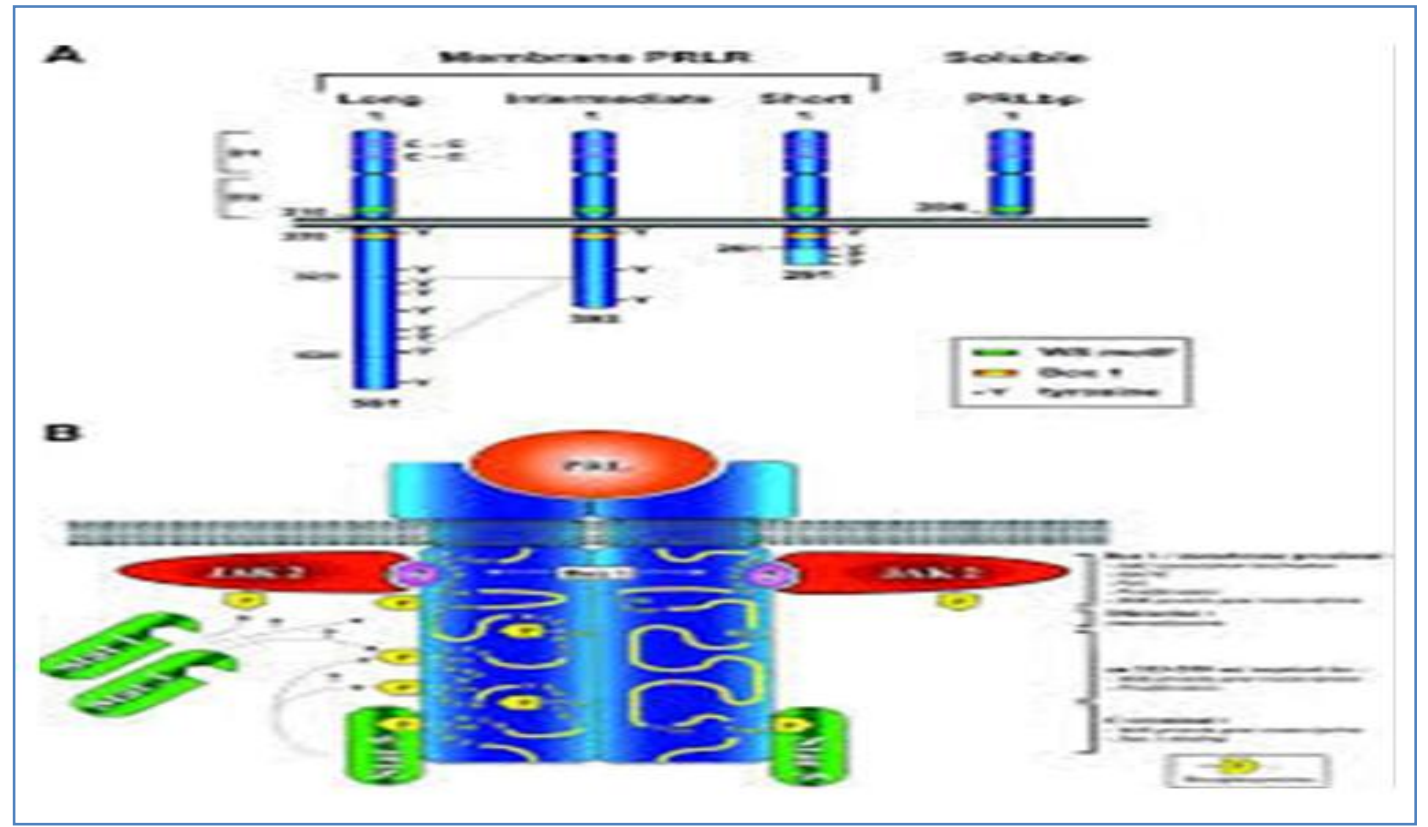

Figure 2: Methylation of Prolactin receptor (Courtesy: Christine Bole-Feysot, Vincent Goffin, Marc Edery, Nadine Binart, Paul A. Kelly. Endocrine Reviews, Volume 19, Issue 3, 1 June 1998, Pages 225268)

\section{Conclusions:}

In mammals, DNA methylation mediates silencing of tissue specific genes in non- expressing cells while combination of transcription factors dictate the expression of undermethylated genes in specialised cells. 
This is greater clarity about potential differences in oxytocin receptor DNA methylation across peripheral tissues currently collected in human studies in relation to central brain tissue OXTR processes. If these fundamentals can be established, progress would be facilitated by increased homogeneity in study design, including phenotypic definition and measurement. This includes greater investment in high quality measurement, such as micro-coding of social interaction using gold-standard protocols, for example, human attachment behaviour, within observational designs. Prospective new drugs inhibiting the methyl transferase enzymes have opened new vistas for clinical therapeutics.

\section{References:}

1. MG Tyagi, $\mathrm{P}$ Bhargava and $\mathrm{K}$ Ernest. Differential cardiovascular responses to oxytocin in male and female rats; influence of platelet activating factor. Asia Pacific Jr.Pharmacol.2003, 16(1): 23-28

2. M G Tyagi. Oxytocin potentiates carbachol induced lacrimation in female Wistar rats. Biomed.Res.2007, 18(2), 103-105

3. $A L$ Smith, SM Freeman, TE Barhhart, DH Abott, EO Ahlers, DL Kukis, KL Bales, MM Goodman, LJ Young. Initial investigation of three selective and potent small molecule oxytocin receptor PET ligands in new world monkeys. Biorg.Med.Chem.Lett.26 (14), 3370-3375, 2016

4. Tahiliani $M$, Koh KP, Shen $Y$, Pastor WA, Bandukwala $H$, Brudno $Y$, Agarwal S, Iyer LM, Liu DR, Aravind L, Rao A. 2009. Conversion of 5-methylcytosine to 5hydroxymethylcytosine in mammalian DNA by MLL partner TET1. Science 324: 930-935.

5. Ito S, Shen L, Dai Q, Wu SC, Collins LB, Swenberg JA, He C, Zhang Y. 2011.Tet proteins can convert 5-methylcytosine to 5-formylcytosine and 5-carboxylcytosine. Science 333: 1300-1303

6. He YF, Li BZ, Li Z, Liu P, Wang Y, Tang $Q$, Ding J, Jia Y, Chen Z, Li L, et al 2011. Tet- mediated formation of 5-carboxylcytosine and its excision by TDG in mammalian DNA. Science 333: 1303-1307

7. Chagnon YC, Potvin O, Hudon C, Preville $M$. DNA methylation and single nucleotide variants in the brain derived neurotrophic factor (BDNF) and oxytocin receptor (OXTR) genes are associated with anxiety/depression in older women. Front Genet. 2015;6:230.

8. Bell $A F$, Carter CS, Steer CD, Golding J, Davis JM, Steffen AD, Rubin LH,Lillard TS, Gregory SP, Harris JC, Connelly JJ. Interaction between oxytocin receptor DNA methylation and genotype is associated with risk of postpartum depression in women without depression in pregnancy. Front.Genet. 2015;6:243.

9. V N Muller, JN Laverriere, D Gourdji. Site specific methylation of rat prolactin and growth hormone promoters correlates with gene expression. Mol.Cell Biol.32453254, 1996

10. Boyes, J., and A. Bird. 1992. Repression of genes by DNA methylation depends on CpG density and promoter strength: evidence for involvement of a methyl-CpG binding protein. EMBO J. 11:327-333.

11. Mizumoto $Y$, Kimura $T$, Ivell R. A genomic element within the third intron of the human oxytocin receptor gene may be implicated in transcription suppression. Mol Cell Endocrinol. 1997;135(2):129-38

12. Brandeis, M., D. Frank, I. Keshet, Z. Siegfried, M. Mendelsohn, A. A. Nemes, V. Temper, A. Razin, and H. Cedar. 1994. Sp1 elements protect a $\mathrm{CpG}$ island from de novo methylation. Nature (London) 371:435-438

13. Puglia MH, Lillard TS, Morris JP, Connelly JJ. Epigenetic modification of the oxytocin receptor gene influences the perception of anger and fear in the human brain. PNAS. 2015;112(11):3308-13.

14. Unternaehrer $E$, Luers $P$, Mill J, Dempster E, Meyer AH, Staehli S, Lieb R,Hellhammer 
DH, Meinischmidt G. Dynamic changes in DNA methylation of stress-associated genes (OXTR, BDNF) after acute psychosocial stress. Transl. Psychiatry. 2012;2(8):150.

15. Unternaehrer $\mathrm{E}$, Meyer AH, Burkhardt SCA, Dempster E, Staehli S, Theill N, Lieb R, Meinischmidt G. Childhood maternal care is associated with DNA methylation of the genes for brain-derived neurotrophic factor (BDNF) and oxytocin receptor (OXTR) in peripheral cells adult men and women. Stress.2015;18(4):451-61.

16. Cappi $C$, Diniz JB, Requena $G L$, Lourenço $T$, Lisboa BCG, Batistuzzo MC,Marques AH, Hoexter MQ, Pereira CA, Miguel EC, Brentani $H$. Epigenetic evidence for involvement of the oxytocin receptor gene in obsessive-compulsive disorder. BMC Neurosci. 2016;17(1):79.

17. Unternaehrer $\mathrm{E}$, Bolten $\mathrm{M}$, Nast I, Staehli $\mathrm{S}$, Meyer AH, Dempster E,Hellhammer DH, Lieb R, Meinlschmidt G. Maternal adversities during pregnancy and cord blood oxytocin receptor (OXTR) DNA methylation. Soc. Cogn Affect Neurosci. 2016;11(9):1460-70.

18. Kimmel M, Clive M, Gispen F, Guintivano J, Brown T, Cox O, Beckmann MW, Kornhuber J, Fasching PA, Osborne LM, Binder E, Payne JL, Kaminsky Z. Oxytocin receptor DNA methylation in postpartum depression. Psychoneuroendocrinology. 2016;69:150-60.

19. Ziegler C, Dannlowski U, Brauer D, Stevens $\mathrm{S}$, Laeger I, Wittmann $\mathrm{H}$, Kugel $\mathrm{H}$, Dobel C, Hurlemann R, Reif A, Lesch K-P, Heindel W, Kirschbaum C, Arolt V, Gerlach AL, Hoyer J, Deckert J, Zwanzger P, Domschke K. Oxytocin receptor gene methylation: converging multilevel evidence for a role in social anxiety. Neuropsychopharmacol. 2015;40:1528-38.

20. Liu, X.; Robinson, G.W.; Wagner, K.U.; Garrett, L.; WynshawBoris, A.; Hennighausen, L. 1997: Stat5a is mandatory

for adult mammary gland development and lactogenesis. Genes and development 11: 179-186.

21. K. Singh, K. Swanson, C. Couldrey, H-M. Seyfert and K. Stelwagen.Proceedings of the New Zealand Society of Animal Production 2009. Vol 69: 57-59 DNA methylation events associated with the suppression of milk protein gene expression during involution of the bovine mammary gland.

22. Russell GJ, Walker PM, Elton RA, SubakSharpe JH. Doublet frequency analysis of fractionated vertebrate nuclear DNA. J Mol Biol. 1976; 108:1-23

23. Coulondre C, Miller JH, Farabaugh PJ, Gilbert W. Molecular basis of base substitution hotspots in Escherichia coli. Nature. 1978; 274:775-780

24. Cho J, Kimura $H$, Minami T, Ohgane J, Hattori N, Tanaka S, Shiota K. DNA methylation regulates placental lactogen I gene expression. Endocrinology. 2001; 142:3389-3396.

25. J. P. Gouin, Q. Q. Zhou, L. Booij, M. Boivin, S. M. Côté, M. Hébert, I. OuelletMorin, M. Szyf, R. E. Tremblay, G. Turecki \& F. Vitaro. Associations among oxytocin receptor gene (OXTR) DNA methylation in adulthood, exposure to early life adversity, and childhood trajectories of anxiousness. Scientific Reportsvolume 7,Article number: 7446 (20 17), 1-14

26. Shuxia L, D Zhu, H Duan, A Ren, D Glintborg, M Andersen, V Skov, M Thomassen, T Kruse, G Tan. Oncotarget, 2017, 8: 20656-2066

27. Y Nakaya, K Kizaki, T Takahashi, DV Patel, K Hashizumi. BMC Molecular Biol.10 (1), 19, 2009

28. Jack A, Connelly JJ, Morris JP. DNA methylation of the oxytocin receptorgene predicts neural response to ambiguous 
Dr Manoj G Tyagi et al., Journal of Biomedical and Pharmaceutical Research

social stimuli. Front Hum Neurosci. 2012;6 (280):1-7.

29. ME Yuksel, B Yuceturk, OF Karatas, M Ozen, B Dogangen. Jr.of Neurogenetics, 30 (3-4), 280-284, 2016

30. LK Durrin, JL Weber and J Gorki. Chromatin structure, transcription and methylation of the prolactin gene domain in pituitary tumors of Fisher 344 rats. J.Biol.Chem.259, 7086-7093, 1984

31. Laverriere, J. N., Muller, M., Buisson, N., Tougard, C., Tixiervidal, A., Martial, J. A., and Gourdji, D. (1986) Differential implication of deoxyribonucleic acid methylation in rat prolactin and rat growth hormone gene expressions a comparison between rat pituitary cell strains. Endocrinology, 118 (1): 198-206

32. Ghoshal K, Datta J, Majumdar S, Bai S, Kutay $\mathrm{H}$, Motiwala J, Jacob ST. 5-azadeoxycytidine induces selective degradation of DNA methyltransferase 1 by a proteosomal pathway that requires the KEN box bromoadjacent homology domain and nuclear localization signal. Mol.Cell.Biol.2005; 25: 4727-4741.

33. J Peedicayil, D R Grayson and D Avramopoulous. Epigenetics in Psychiatry, Elsevier, 2014. 